\title{
MODEL ZA UPRAVLJANJE PROVIZIJSKIM PRIHODIMA U AGENCIJAMA ZA ZASTUPANJE U OSIGURANJU
}

\author{
MODEL FOR IMPROVING PROVISIONS INCOME \\ IN INSURANCE AGENCIES
}

\begin{abstract}
SAŽETAK: Planske računovodstvene informacije formirane primjenom povijesnih računovodstvenih informacija značajne su u planiranju i realizaciji poslovnih ciljeva. Iz tog razloga nameće se potreba uspostave novih modela koji generiraju planske računovodstvene informacije za unaprjeđenje poslovanja i procesa odlučivanja. Istraživanje se usmjerilo na formiranje novog modela za upravljanje poslovanjem agencija za zastupanje u osiguranju. Zastupanje u osiguranju obuhvaća predlaganje i obavljanje poslova pripreme i sklapanja ugovora o osiguranju za osiguravajuća društva. Najznačajniji prihodi agencija za zastupanje u osiguranju su provizije od osiguravajućeg društva na koju stječu pravo početkom važenja ugovora o osiguranju.

Primjenom računovodstvenih informacija, uz korištenje statističkih zakonitosti i matematičkim programiranjem, uspostavljen je novi model koji pruža planske računovodstvene informacije za realizaciju planiranih prihoda od provizija. Računovodstvene informacije kao polazišna osnova korištene su kroz kombinaciju statističkog modeliranja koji se implementirao u matematičko programiranje za dobivanje planskih računovodstvenih informacija za postizanje planiranog cilja. Rezultat toga su planirane vrijednosti bruto premije po vrstama osiguranja za realizaciju ukupnog planiranog provizijskog prihoda. Primjenjivost modela prikazana je na primjeru agencije za zastupanje u osiguranju.
\end{abstract}

KLJUČNE RIJEČI: računovodstvene informacije, prihodi od provizije, bruto premija, vrste osiguranja, agencije za zastupanje u osiguranju

SUMMARY: Planned accounting information formed by applying historical accounting information are significant in planning and achieving business goals. Because of this reasons, there is a need to establish new models that will improve the business. This research is focused on the creation of a new model for managing the business of insurance

Izv. prof. dr. sc. Ticijan Peruško, Sveučilište Jurja Dobrile u Puli, Fakultet ekonomije i turizma „Dr. Mijo Mirkovič“ Pula, P. Preradovića 1/1,52100 Pula, Hrvatska, tperusko@unipu.hr 
agencies. Their main operating income is their commission income from the sale of insurance for insurance companies.

By applying accounting information, using statistical regularities and mathematical programming, an accounting model has been established that provides planned accounting information for the realization of planned commission income. Accounting information as a starting point was used through a combination of statistical modeling that was implemented in mathematical programming to obtain planned accounting information to achieve the intended goal. As a result, we have got the planned values of gross premiums by type of insurance for the realization of the total planned commission income. The applicability of the model is exemplified by the insurance agency.

KEYWORDS: accounting information, commission income, gross premium, types of insurance, insurance representation agencies

\section{UVOD}

Zastupanje u osiguranju obuhvaća djelatnost pokretanja, predlaganja ili obavljanja poslova pripreme i sklapanja ugovora o osiguranju za osiguravajuća društva. Agencije za zastupanje u osiguranju obavljaju poslove zastupanja kao djelatnost koja glavne prihode ostvaruje od provizija iz prodaje proizvoda osiguranja, odnosno sklapanja ugovora o osiguranju za osiguravajuća društva.

Osiguravajuća društva obračunavaju proviziju agencijama za zastupanje u osiguranju na vrijednost bruto premije ugovorenog proizvoda osiguranja. Bruto premija je cijena osiguranja koju osiguranik uplaćuje osiguravatelju za ugovoreno osiguranje.

Iz međupovezanosti bruto premija i prihoda od provizija polazi hipoteza istraživanja o uspostavi znanstvenog modela koji će generirati planske računovodstvene informacije za upravljanje provizijskim prihodima. Statistički modeli i matematičko programiranje korišteni su u razradi hipoteze i testiranju reprezentativnosti.

Doprinos istraživanja je u stvaranju novog modela za unaprjeđenje procesa poslovnog planiranja putem uspostave korelativnih odnosa između računovodstvenih informacija u optimizacijskim procesima. Rezultat toga su planske računovodstvene informacije o provizijskim prihodima i bruto premiji.

Cilj istraživanja postigao se implementiranjem povijesnih računovodstvenih informacija u statističko modeliranje za provođenje postupka matematičkog programiranja. Rezultat toga je model koji primjenom povijesnih računovodstvenih informacija generira planske računovodstvene informacije za realizaciju planiranog provizijskog prihoda.

Kroz prikaz metodologije istraživanja obuhvaćene su teorijske i znanstvene osnove na kojima se izgradio model, a primjena modela prikazana je na primjeru agencije za zastupanje u osiguranju. U razradi modela težilo se znanstvenoj utvrdivosti svih elemenata modela uključujući i granice ograničenja u matematičkom programiranju. Slijedom toga, rezultat istraživanja je znanstveni model koji produbljuje materiju industrije osiguranja, a pruža planske računovodstvene informacije za proces donošenja odluka o planskim veličinama bruto premije za realizaciju ukupnog planiranog prihoda od provizije uz uvažavanje tržišnih ograničenja. 


\section{PREGLED LITERATURE}

Istraživanje i primjena optimizacije u industriji osiguranja područje je od posebnog interesa kod istraživača jer omogućuje znanstveno produbljivanje i praktičnu primjenu. Drandel (1977) je primijenio linearni model programiranja kako bi odredio optimalnu raspodjelu imovine osiguravajućeg društva za maksimiziranje dobiti. Li i Huang (1996) razvili su model primijenjen za optimizaciju sastava portfelja osiguranja i portfelja ulaganja s obzirom na razinu praga rizika osiguravatelja, kao i za generiranje učinkovite granice podešavanjem razine praga rizika osiguravatelja.

Brockett i Xia (1995) prikazali su operativne metode istraživanja primijenjene za modeliranje i rješavanje brojnih problema u znanosti o osiguranju. U svom istraživanju prikazali su primjenu matematičkog programiranja u industriji osiguranja. Sen i Higle (1999) razmatraju razne modele temeljene na linearnom programiranju koji se u poslovnoj neizvjesnosti mogu koristiti za planiranje. U radu su istražili i razradili modele dvostupanjskih i višestepenih formulacija sustava linearnog programiranja.

Garg et al (2006) opisuju razvoj višefaznog stohastičkog modela linearnog programiranja za osiguravajuću djelatnost. Područje autoosiguranja i matematičkog programiranja istraživali su Yeo et al. (2002) koji su u svom radu prikazali dokaze o koristima pristupa koji kombinira rudarenje podataka i matematičkog programiranja za određivanje premije za naplatu po policama automobilskog osiguranja kako bi došli do optimalnog portfelja.

Peng et al. (2007) primijenili su linearno programiranje za utvrđivanje prijevara u zdravstvenom osiguranju. Schleef (2007) je istraživanje usmjerio na razvoj modela linearnog programiranja za upravljanje životnim osiguranjem sa ciljem maksimiziranja neto sadašnje vrijednosti kombinacijom životnog osiguranja i samoosiguranja. Hill et al. (2007) izradili su model matematičkog programiranja i njegovu računalnu implementaciju za upravljanje imovinom finske kompanije za mirovinsko osiguranje.

Rao, Duta i Basu (2018) razvili su sustav podrške za odlučivanje temeljene na modelu upravljanja imovinom za osiguravajuće društvo koji primjenjuje višefazno stohastičko linearno programiranje. Krasheninnikova et al. (2019) koristili su programiranje za optimizaciju cjenovne strategije za obnavljanje portfelja osiguranja. Istraživanje novih modela baziranim na matematičkom programiranju primjenjuju se za znanstveno produbljenje materije osiguranja, unaprjeđenje procesa planiranja i realizaciju poslovnih ciljeva u industriji osiguranja.

\section{METODOLOGIJA ISTRAŽIVANJA}

Poslovna uspješnost, promatrana kroz računovodstvene kategorije, razlika je ostvarenih prihoda i rashoda. $\mathrm{U}$ tom procesu potrebno je upravljati prihodima i rashodima. S tog pogleda agencije za zastupanje u osiguranju mogu poboljšati svoju poslovnu uspješnost kroz nekoliko pristupa. To se postiže povećanjem prihoda uz konstantne rashode, smanjenjem rashoda uz konstante prihode i povećanjem prihoda uz neproporcionalno povećanje rashoda.

Maksimiziranje prihoda, odnosno minimiziranje rashoda u cilju maksimizacije poslovnog rezultata po vrsti osiguranja, uz uvažavanje ograničenja, postiže se tehnikom linearnog programiranja (Andrijašević, Petranović, 1999). U planiranju visine prihoda i rashoda 
potrebno je utvrditi planske veličine premije po vrsti osiguranja. Planske veličine utvrđuju se primjenom povijesnih računovodstvenih informacija i kretanja na tržištu osiguranja.

Provedenim istraživanjem usmjerilo se na izradu modela koji obuhvaća glavne elemente uspješnosti poslovanja agencija za zastupanje u osiguranju, a to su prihodi od provizija i bruto premija po vrsti osiguranja. U postupku izgradnje optimizacijskog modela primijenjena je statistička metoda regresije i matematičko programiranje.

Regresijska analiza često je korištena statistička metoda za objašnjenje odnosa među varijablama, a koristi se u mnogim područjima primijenjenih znanosti kao što su statističke, akutarske, financijske i ekonomske studije. (Erdemir, 2019). Statistička metoda regresijske analize utvrđuje postojanje međuodnosa između promatranih pojava. Primjenom ove statističke metode pronalazi se kretanje trenda vrijednosti ovisno o promjenama analiziranih varijabli. Tako se u regresijskoj analizi pronalaze odnosi između dviju i više pojava, gdje se pojave predočavaju kao zavisne i nezavisne varijable. Primjenom regresijske analize formira se regresijski model koji omogućuje predviđanje zavisne varijable uslijed promjene nezavisne varijable. Trend kretanja promatranih varijabli pokazuje dinamičnu srednju vrijednost izraženu matematičkom funkcijom za pokazivanje tendencije neke promjene. Model linearne regresije svodi se na utvrđivanje analitičkog izraza koji najbolje predočuje empirijske podatke. Opći model linearne regresije je (Aczel, Sounderpandian, 2009):

$$
Y=f(x)+e
$$

Ako je funkcionalni dio model oblika:

$$
f(x)=a+\beta X
$$

Model postaje:

$$
Y=\alpha+\beta X+e
$$

Regresijska analiza provodi se na temelju n parova vrijednosti $\mathrm{X}$ i $\mathrm{Y}$, tj. parova $\left(\mathrm{x}_{1}, \mathrm{y}_{1}\right)$, $\left(\mathrm{x}_{2}, \mathrm{y}_{2}\right), \ldots,\left(\mathrm{x}_{\mathrm{i}}, \mathrm{y}_{\mathrm{i}}\right), \ldots\left(\mathrm{x}_{\mathrm{n}}, \mathrm{y}_{\mathrm{n}}\right)$, pa se model predočuje sustavom $\mathrm{n}$ jednadžbi.

$$
y_{i}=d\left(x_{i}\right)+e_{i}
$$

odnosno:

$$
y_{i}=\alpha+\beta x_{i}+e_{i}, \quad i=1,2, \ldots, n
$$

Model linearne regresije primjenjuje se u istraživanju međuodnosa bruto premije osiguranja i prihoda od provizije. Linearni modeli primjenjivi su jer se pojave u osiguranju promatraju kroz specifične linearne kombinacije varijabli ocjenjivanja (Garido et al., 2019).

Polazeći od pretpostavke postojanja međupovezanosti koja se može izraziti statističkim modelom između bruto premije i prihoda od provizije testiraju se međuodnosi korelacijskom analizom između godišnje bruto premije po vrstama osiguranja i prihoda od pro- 
vizije. Pri tome se definiraju zavisne i nezavisne varijable koje su potrebne za provođenje statističke metode regresije. Zavisna varijabla je provizijski prihod, a nezavisna varijabla godišnja bruto premija. Statističkim modelima iskazuje se povezanost između predmetnih varijabli, putem kojih se izvode statistički modeli po vrstama osiguranja. Ti statistički modeli, osim što je njima prikazana statistički izvedena međupovezanost zavisne i nezavisne varijable, služe i za izračun promjena visine prihoda u odnosu na promjenu bruto premije. Model linearne regresije koji obuhvaća predmetne varijable prikazuje se izrazom:

$$
\begin{gathered}
\hat{\mathrm{Y}}=\alpha+\beta x++e_{i} \\
\beta=\frac{\sum_{i=1}^{n} x y-n \overline{x y}}{\sum_{i=1}^{n} x-n \bar{x}} \\
\alpha=\bar{y}-b \bar{x} \\
r^{2}=\frac{\sum_{i=1}^{n}\left(\bar{y}_{i}-\bar{y}\right)^{2}}{\sum_{i=1}^{n}\left(y_{i}-\bar{y}\right)^{2}}=\frac{a \sum_{i=1}^{n} y_{i}+b \sum_{i=1}^{n} x_{i} y_{i}-n \bar{y}^{2}}{\sum_{i=1}^{n} y_{i}^{2}-n \bar{y}^{2}}, \quad 0 \leq r^{2} \leq 1 . \\
\begin{array}{l}
\hat{Y}-\text { prihod od provizije } \\
\beta-\text { konstanti član } \\
\beta-\text { regresijski koeficijent koji prikazuje prosječnu promjenu prihoda } \\
\text { uslijed povećanja bruto premije za jednu jedinicu }
\end{array}
\end{gathered}
$$

$\hat{Y}-$ prihod od provizije

$\alpha$ - konstanti član

$\mathrm{x}$ - godišnja bruto premija

$\mathrm{r}^{2}$ - koeficijent determinacije

Primjenom statističkih linearnih modela po vrstama osiguranja dobivaju se prognozirane vrijednosti prihoda od provizija zavisno od povećanja godišnje bruto premije. Zbroj svih provizijskih prihoda po vrstama osiguranja čini ukupni prihod od provizije agencija za zastupanje u osiguranju.

Naredna metoda korištena u izgradnji modela je matematičko programiranje. Standardni oblik problema linearnog programiranja u kojem maksimiziramo ili minimiziramo funkciju cilja, sastoji se u sljedećem (Neralić, 2012):

$$
\max / \min z\left(x_{1}, x_{2}, \ldots, x_{n}\right)=c_{1} x_{1}+c_{2} x_{2}+\ldots+c_{n} x_{n}
$$


uz ograničenja:

$$
\begin{gathered}
a_{11} x_{1}+a_{12} x_{2}+\ldots+a_{1 n} x_{1 n} \leq b_{1} \\
a_{21} x_{1}+a_{22} x_{2}+\ldots+a_{2 n} x_{2 n} \leq b_{2} \\
\cdot \\
\cdot \\
\cdot \\
\cdot \\
a_{m 1} x_{1}+a_{m 2} x_{2}+\ldots+a_{m n} x_{n} \leq b_{m} \\
x_{1} \geq 0, x_{2} \geq 0, \ldots, x_{n} \geq 0
\end{gathered}
$$

Funkcija cilja koja se maximizira ili minimizira $z\left(x_{1}, x_{2}, \ldots, x_{n}\right)$ je linearna pri čemu su $c_{i}, j=1,2, \ldots, n$ koeficijenti funkcije cilja dok su $x_{j}, j=1,2, \ldots, n$ strukturne varijable. Matematičko programiranje bavi se problemima optimizacije u kojima optimizator nailazi na ograničenja. Linearno programiranje promatra probleme u kojima se linearna funkcija cilja mora optimizirati uz uvjete ili ograničenja uz nenegativne varijable odlučivanja. To je formalni postupak optimizacije sustava kod kojih se funkcija cilja i ograničenja mogu izraziti linearnim kombinacijama promjenljivih veličina (Yeo et al.,2002).

U postupak matematičkog programiranja implementiraju se statistički linearni modeli koji imaju funkciju predvidjeti porast bruto premije po vrstama osiguranja gdje se uz kombinaciju planiranih visina godišnjih bruto premija postiže planirani ukupni prihod od provizije. Poslovanje agencija za zastupanje u osiguranju odvija se u području poslovnih ograničenja, te su u postupak linearnog programiranja uvedeni parametri gornjih i donjih ograničenja.

Za donje ograničenje postavljaju se vrijednosti bruto premije u posljednjem promatranom godišnjem razdoblju. Gornje ograničenje obuhvaća maksimalnu visinu prodaje po vrstama osiguranja iskazanu u vrijednosti godišnje bruto premije. Testiranjem godišnjih kretanja iznosa bruto premija po vrstama osiguranja u višegodišnjim razdobljima utvrđuje se pravilnost promjena koja se može izraziti statističkim prognostičkim trend modelima. Slijedom toga, primjenom prognostičkih trend modela određuju se gornja ograničenja u matematičkom programiranju korištenom za formiranje modela. Prognostičkim trend modelima povezuju se godišnja vremenska razdoblja i godišnja bruto premije. Nezavisna varijabla u prognostičkom trend modelu je vrijeme, a zavisna varijabla je godišnja bruto premija.

Tim putem omogućuje se prognoza godišnje visine bruto premije koja svoju utemeljenost ima u znanstvenim metodama. Izbor tipa modela ovisi o reprezentativnosti po vrsti osiguranja. Izbor trend modela proizlazi iz kvalitativne analize, grafičkog prikaza serije, analize prvih ili viših diferencija originalnih ili logaritamskih vrijednosti serije, te statističko-analitičkih postupaka. (Šošić. 604.) 
Tablica 1. Predloženi prognostički trend modeli za definiranje gornjih ograničenja u matematičkom programiranju

\begin{tabular}{|l|c|}
\hline \multicolumn{1}{|c|}{ Naziv modela } & Oblik modela \\
\hline Model linearnog trenda & $y_{t}=\alpha+\beta x_{t}+e_{t}$ \\
\hline Parabolični trend drugog stupnja & $y_{t}=\alpha+\beta_{1} x_{t}+\beta_{2} x_{t}^{2}+e_{t}$ \\
\hline Eksponencijalni trend & $y_{t}=\alpha \beta^{x t} \varepsilon_{t}, \ln y_{t}=\ln \alpha+\ln \beta x_{t}+\ln \varepsilon_{t}$ \\
\hline
\end{tabular}

Izvor: prema autoru

Tako optimizacijski model omogućuje dobivanje planskih računovodstvenih informacija za realizaciju planiranog ukupnog provizijskog prihoda koristeći statističke regresijske modele kojima se povezuje zavisna varijabla prihodi od provizije sa visinom godišnje bruto premije. Donje ograničenje su polazne vrijednosti ostvarene bruto premije po vrsti osiguranja u posljednjoj promatranoj godini. Gornja ograničenja limitirane su vrijednosti prodaje po vrstama osiguranja dobivene regresijskim prognostičkim trend modelima. Informacije koje pruža optimizacijski model omogućuju realizaciju planiranog prihoda uz prikaz kombinacija bruto premija po vrsti osiguranja, uvažavajući tržišna ograničenja u planiranom rastu premije.

\section{PRIMJENA ISTRAŽIVANJA}

Zakonitosti i aplikaciju optimizacijskog modela za upravljanje prihodima prikazat će se na primjeru agencije za zastupanje u osiguranju koje posluje na tržištu Republike Hrvatske. Obuhvaćeno je godišnje razdoblje od 2012. do 2018. godine. Sistematiziran pregled računovodstvenih informacija potrebnih za primjenu modela nalaze se u tablici 2 i tablici 3.

Tablica 2. Godišnje bruto premije u agenciji za zastupanje u osiguranju po vrstama osiguranja u razdoblju od 2012. do 2018. godine.

\begin{tabular}{|c|c|c|c|c|c|c|}
\hline Godina & $\begin{array}{c}\text { Osiguranje } \\
\text { od nezgode }\end{array}$ & $\begin{array}{c}\text { Osiguranje } \\
\text { financijskih } \\
\text { gubitaka }\end{array}$ & $\begin{array}{c}\text { Putno } \\
\text { osiguranje }\end{array}$ & $\begin{array}{c}\text { Osiguranje } \\
\text { od požara }\end{array}$ & $\begin{array}{c}\text { Osiguranje } \\
\text { odgovornosti }\end{array}$ & $\begin{array}{c}\text { Zdravstveno } \\
\text { osiguranje }\end{array}$ \\
\hline 2012 & 763.587 & 190.415 & 256.284 & 1.710 .153 & 606.901 & 3.839 \\
\hline 2013 & 803.018 & 236.893 & 249.350 & 1.898 .284 & 685.260 & 3.256 \\
\hline 2014 & 848.977 & 221.081 & 241.526 & 2.043 .760 & 749.655 & 7.484 \\
\hline 2015 & 857.887 & 249.577 & 235.823 & 2.030 .119 & 849.463 & 41.942 \\
\hline 2016 & 839.873 & 259.832 & 248.686 & 2.064 .690 & 1.111 .709 & 53.849 \\
\hline 2017 & 857.401 & 281.572 & 368.339 & 2.130 .284 & 1.320 .851 & 200.653 \\
\hline 2018 & 870.556 & 324.113 & 407.965 & 2.289 .838 & 1.537 .315 & 391.910 \\
\hline
\end{tabular}

Izvor: interni financijski izvještaji agencije za zastupanje u osiguranju 
Tablica 3. Prihodi od provizije u agenciji za zastupanje u osiguranju po vrstama osiguranja u razdoblju od 2012. do 2018. godine.

\begin{tabular}{|c|c|c|c|c|c|c|}
\hline Godina & $\begin{array}{c}\text { Osiguranje } \\
\text { od nezgode }\end{array}$ & $\begin{array}{c}\text { Osiguranje } \\
\text { financijskih } \\
\text { gubitaka }\end{array}$ & $\begin{array}{c}\text { Putno } \\
\text { osiguranje }\end{array}$ & $\begin{array}{c}\text { Osiguranje } \\
\text { od požara }\end{array}$ & $\begin{array}{c}\text { Osiguranje } \\
\text { odgovornosti }\end{array}$ & $\begin{array}{c}\text { Zdravstveno } \\
\text { osiguranje }\end{array}$ \\
\hline 2012 & 118.665 & 21.919 & 37.066 & 236.245 & 56.700 & 875 \\
\hline 2013 & 156.298 & 20.153 & 36.661 & 265.729 & 60.394 & 826 \\
\hline 2014 & 182.509 & 24.802 & 31.963 & 332.327 & 66.258 & 1.231 \\
\hline 2015 & 189.832 & 34.231 & 36.385 & 345.627 & 84.337 & 5.978 \\
\hline 2016 & 219.154 & 40.986 & 47.644 & 430.499 & 127.996 & 9.104 \\
\hline 2017 & 219.348 & 45.311 & 64.508 & 510.673 & 159.278 & 26.827 \\
\hline 2018 & 218.700 & 52.196 & 67.068 & 499.835 & 196.846 & 48.195 \\
\hline
\end{tabular}

Izvor: interni financijski izvještaji agencije za zastupanje u osiguranju

Statistička metoda linearne regresije primjenjuje se za dobivanje regresijskih modela kojima su povezani prihodi od provizije i bruto premija po vrsti osiguranja. Pri tome se statistički modeli koriste za prognozu promjene provizijskih prihoda kao zavisne varijable koja se mijenja u odnosu na promjenu vrijednosti bruto premije kao nezavisne varijable. Po svakoj vrsti osiguranja izgrađuju se linearni regresijski modeli. Testirani su po statističkim parametrima, a dobiveni rezultati i regresijski modeli iskazani su u tablici.

Tablica 4. Statistički parametri linearnih regresijskih modela po vrsti osiguranja

\begin{tabular}{|c|l|l|l|l|c|}
\hline $\begin{array}{c}\text { Red } \\
\text { br. }\end{array}$ & \multicolumn{1}{|c|}{ OPIS } & \multicolumn{1}{|c|}{ Regresijski model } & \multicolumn{1}{c|}{$\mathbf{r}^{2}$} & \multicolumn{1}{c|}{$\mathbf{p}$} & $\begin{array}{c}\text { Standardna } \\
\text { pogreška }\end{array}$ \\
\hline 1. & Osiguranje od nezgode & $\mathrm{y}=0,9120 \mathrm{x}-574.657,6224$ & 0,822820 & 0,0048038 & 17581,20 \\
\hline 2. & $\begin{array}{l}\text { Osiguranje od financijskih } \\
\text { gubitaka }\end{array}$ & $\mathrm{y}=0,2643 \mathrm{x}-32.352,4768$ & 0,835218 & 0,003986 & 5535,75 \\
\hline 3. & Putno osiguranje & $\mathrm{y}=0,1931 \mathrm{x}-9.490,3930$ & 0,890953 & 0,0013887 & 5212,06 \\
\hline 4. & Osiguranje od požara & $\mathrm{y}=0,5350 \mathrm{x}-708.417,7354$ & 0,800338 & 0,0065375 & 53226,143 \\
\hline 5. & Osiguranje odgovornosti & $\mathrm{y}=0,1560 \mathrm{x}-45.526,3432$ & 0,99449 & $7,64 \mathrm{E}-07$ & 4465,77 \\
\hline 6. & Zdravstveno osiguranje & $\mathrm{y}=0,1225 \mathrm{x}+986,6568$ & 0,997058 & $1,5947 \mathrm{E}-07$ & 1064,83 \\
\hline
\end{tabular}

Izvor: izračun autora

Regresijski modeli po vrstama osiguranja uključuju se u matematičko programiranje za utvrđivanje kombinacije vrijednosti godišnje bruto premije po vrstama osiguranja za postizanje planirane vrijednosti ukupnog provizijskog prihoda. S obzirom da je prodaja po vrstama osiguranja ograničena i pod utjecajem je potražnje i konkurentskih pozicija na tržištu osiguranja, uspostavlja se gornje ograničenje u vidu prognozirane godišnje bruto premije koja se može realizirati po vrstama osiguranja.

Godišnja bruto premija iz promatranog sedmogodišnjeg razdoblja predstavlja početne podatke za predviđanje prognoziranih mogućnosti u prodaji osiguranja. Za prognozu gor- 
njeg ograničenja koristi se prognostički trend model. U tom modelu vrijeme je nezavisna varijabla, dok je godišnja bruto premija zavisna varijabla. Primjenom podataka o visini godišnjih bruto premija kroz godišnja razdoblja, prikazanih u tablici 2, oformljeni su reprezentativni prognostički trend modeli, te putem njih izračunata je prognozirana visina bruto premija koja se može ugovoriti za naredno planirano godišnje razdoblje.

Tablica 5. Regresijski trend modeli i prognozirana vrijednost bruto premija po vrsti osiguranja

\begin{tabular}{|c|l|l|c|c|}
\hline $\begin{array}{c}\text { Red } \\
\text { br. }\end{array}$ & \multicolumn{1}{|c|}{ OPIS } & \multicolumn{1}{|c|}{ Regresijski model } & \multicolumn{1}{|c|}{$\mathbf{r}^{2}$} & $\begin{array}{c}\text { Ograničenje } \\
\text { (bruto premija) }\end{array}$ \\
\hline 1. & Osiguranje od nezgode & $\mathrm{y}=15.020 \mathrm{x}+774.390$ & 0,73 & 894.550 \\
\hline 2. & $\begin{array}{l}\text { Osiguranje od financijskih } \\
\text { gubitaka }\end{array}$ & $\mathrm{y}=1.566 \mathrm{x}^{2}+6.367 \mathrm{x}+195.124$ & 0,92 & 346.326 \\
\hline 3. & Putno osiguranje & $\mathrm{y}=10.801 \mathrm{x}^{2}-61.404 \mathrm{x}+316.443$ & 0,92 & 516.476 \\
\hline 4. & Osiguranje od požara & $\mathrm{y}=79.428 \mathrm{x}+1.706 .163$ & 0,89 & 2.341 .587 \\
\hline 5. & Osiguranje odgovornosti & $\mathrm{y}=158017 \mathrm{x}+348096$ & 0,94 & 1.612 .232 \\
\hline 6. & Zdravstveno osiguranje & $\mathrm{y}=19.368 \mathrm{x}^{2}-97.615 \mathrm{x}+103.506$ & 0,97 & 562.194 \\
\hline
\end{tabular}

Izvor: izračun autor

U postupku matematičkog programiranja se implementacijom linearnih regresijskih modela po vrsti osiguranja izračunavaju prihodi od provizije u odnosu na promjenu visine bruto premije. Cilj ovog matematičkog programiranja je pronaći rješenja u kombinaciji bruto premije, u rasponu donjeg i gornjeg ograničenja, kojima će se realizirati planirani ukupan provizijski prihod. Prilikom odabira bruto premije po vrsti osiguranja primjenjuje se načelo najkraćeg puta, odnosno kombinacije povećanja bruto premije prema vrsti osiguranja koja će rezultirati onim optimalnim povećanjem ukupne premije koja će udovoljiti zadanom cilju, a to je planirani ukupni prihod od provizije. Proces optimizacije tako obuhvaća bruto premiju po vrstama osiguranja u posljednjoj godini kao donje ograničenje, regresijske modele za prognozu visine prihoda od provizije, a gornje ograničenje predstavlja prognoziranu vrijednost ugovorene bruto premije po vrstama osiguranja dobivene regresijskim trend modelima. Varijable uključene u optimizacijski model i uvjeti programiranja prikazani su u tablici. 
Tablica 6. Prikaz podataka uključenih u optimizacijski model za upravljanje provizijskim prihodima u agenciji za zastupanje u osiguranju.

\begin{tabular}{|c|c|c|c|c|c|}
\hline \multirow[t]{2}{*}{$\begin{array}{c}\text { Red } \\
\text { br. }\end{array}$} & \multirow[t]{2}{*}{ OPIS } & $\begin{array}{l}\text { Bruto } \\
\text { premija } \\
2018 \mathrm{~g} .\end{array}$ & \begin{tabular}{|c|} 
Prihodi od \\
provizija \\
2018 g.
\end{tabular} & Regresijski modeli & $\begin{array}{c}\text { Ograničenje } \\
\text { (bruto } \\
\text { premija) } \\
\end{array}$ \\
\hline & & $\mathbf{x}$ & $\mathbf{y}$ & q & $\mathbf{z}$ \\
\hline 1. & Osiguranje od nezgode & 870.556 & 218.700 & $y=0,9120 x-574.657,6224$ & 894.550 \\
\hline 2. & $\begin{array}{l}\text { Osiguranje od } \\
\text { financijskih gubitaka }\end{array}$ & 324.113 & 52.196 & $y=0,2643 x-32.352,4768$ & 346.326 \\
\hline 3. & Putno osiguranje & 407.965 & 67.068 & $y=0,1931 x-9.490,3930$ & 516.476 \\
\hline 4. & Osiguranje od požara & 2.289 .838 & 499.835 & $y=0,5350 x-708.417,7354$ & 2.341 .587 \\
\hline 5. & Osiguranje odgovornosti & 1.537 .315 & 196.846 & $y=0,1560 x-45.526,3432$ & 1.612 .232 \\
\hline 6. & Zdravstveno osiguranje & 391.910 & 48.195 & $y=0,1225 x+986,6568$ & 562.194 \\
\hline 7. & UKUPNO & 5.821 .697 & 1.082 .840 & & 6.273 .367 \\
\hline
\end{tabular}

Izvor: tablice 2-5.

Uvjeti programiranja $u z \mathrm{x}_{\mathrm{p}}$ vrijednosti prognozirane bruto premije su:

$$
\begin{gathered}
\min \left(\mathrm{x}_{7 \mathrm{p}}\right) \\
\mathrm{x}_{7 \mathrm{p}}=\mathrm{x}_{1 \mathrm{p}}+\mathrm{x}_{2 \mathrm{p}}+\mathrm{x}_{3 \mathrm{p}}+\mathrm{x}_{4 \mathrm{p}}+\mathrm{x}_{5 \mathrm{p}}+\mathrm{x}_{6 \mathrm{p}}
\end{gathered}
$$

uz donja i gornja ograničenja

$$
\begin{aligned}
& x_{1} \leq x_{1 p} \geq z_{1} \\
& x_{2} \leq x_{2 p} \geq z_{2} \\
& x_{3} \leq x_{3 p} \geq z_{3} \\
& x_{4} \leq x_{4 p} \geq z_{4} \\
& x_{5} \leq x_{5 p} \geq z_{5} \\
& x_{6} \leq x_{6 \mathrm{p}} \geq z_{6}
\end{aligned}
$$

ciljani ukupni prihod od provizije $\mathrm{y}_{\mathrm{p}} \mathrm{je}$

$$
\begin{gathered}
\mathrm{y}_{7 \mathrm{p}}=1.170 .000 \mathrm{kn} \\
\mathrm{y}_{7 \mathrm{p}}=\mathrm{y}_{1 \mathrm{p}}+\mathrm{y}_{2 \mathrm{p}}+\mathrm{y}_{3 \mathrm{p}}+\mathrm{y}_{4 \mathrm{p}}+\mathrm{y}_{5 \mathrm{p}}+\mathrm{y}_{6 \mathrm{p}}
\end{gathered}
$$

pri čemu je

$$
\begin{aligned}
& \mathrm{y}_{1 \mathrm{p}}=0,9120 \mathrm{x}-574.657,6224 \\
& \mathrm{y}_{2 \mathrm{p}}=0,2643 \mathrm{x}-32.352,4768 \\
& \mathrm{y}_{3 \mathrm{p}}=0,1931 \mathrm{x}-9.490,3930 \\
& \mathrm{y}_{4 \mathrm{p}}=0,5350 \mathrm{x}-708.417,7354 \\
& \mathrm{y}_{5 \mathrm{p}}=0,1560 \mathrm{x}-45.526,3432 \\
& \mathrm{y}_{6 \mathrm{p}}=0,1225 \mathrm{x}+986,6568
\end{aligned}
$$


Tablica 7. Prognozirane vrijednosti bruto premije po vrstama osiguranja za realizaciju planiranih ukupnih provizijskih prihoda

\begin{tabular}{|c|l|c|c|}
\hline $\begin{array}{c}\text { Red. } \\
\text { br. }\end{array}$ & \multicolumn{1}{|c|}{ OPIS } & $\begin{array}{c}\text { Prognozirana bruto } \\
\text { godišnja premija }\end{array}$ & $\begin{array}{c}\text { Prognozirani godišnji } \\
\text { prihodi od provizije }\end{array}$ \\
\hline 1. & Osiguranje od nezgode & 894.550 & 241.148 \\
\hline 2. & $\begin{array}{l}\text { Osiguranje od financijskih } \\
\text { gubitaka }\end{array}$ & 346.327 & 59.177 \\
\hline 3. & Putno osiguranje & 473.466 & 81.933 \\
\hline 4. & Osiguranje od požara & 2.341 .588 & 544.405 \\
\hline 5. & Osiguranje odgovornosti & 1.537 .315 & 194.329 \\
\hline 6. & Zdravstveno osiguranje & 391.910 & 49.007 \\
\hline 7. & UKUPNO & $\mathbf{5 . 9 8 5 . 1 5 6}$ & $\mathbf{1 . 1 7 0 . 0 0 0}$ \\
\hline
\end{tabular}

Izvor: izračun autora

Optimizacijskim modelom dobiveni su iznosi godišnje bruto premije po vrstama osiguranja koji udovoljavaju uvjetima minimiziranja porasta bruto premije po vrstama osiguranja, uz postavljena ograničenja, za postizanje planirane visine ukupnih prihoda od provizije. Pregledom dobivenih vrijednosti uviđa se da je vrijednost godišnje bruto premije osiguranja od nezgode i osiguranja od financijskih gubitaka planirana u visini gornjeg ograničenja. Kod putnog osiguranja potrebno je povećati prodaju za $65.501 \mathrm{kn}$ odnosno za $16 \%$ Osiguranje od požara također je planirano u visini gornjeg ograničenja prognozirane bruto premije. Osiguranje od odgovornosti i zdravstveno osiguranje nemaju promjene u visini bruto premije u odnosu na početno stanje portfelja.

Dodatna odlika prikazanog optimizacijskog modela je fleksibilnost u izradi scenarija za realizaciju ciljeva. Fleksibilnost modela izražena je u pogledu uvođenja novih ograničenja sukladno zahtjevima poslovanja i tržišta osiguranja. Ta fleksibilnost ogleda se u uvođenju novih zahtjeva u varijable ograničenja. To se može prikazati na primjeru osiguranja od odgovornosti gdje je iznos planirane bruto premije jednak iznosu početnog stanja. Zbog visine prihoda od provizije u odnosu na druge vrste osiguranja nije došlo do promjene u planiranoj vrijednosti godišnje bruto premije ove vrste osiguranja. Optimizacijski model omogućuje uvođenje dodatnih ograničenja kroz uvjetovanje visine planirane bruto premije. $\mathrm{Na}$ ovaj način omogućeno je kreiranje raznovrsnih scenarija za upravljanje provizijskim prihodima prilagođenim poslovnim ciljevima agencija za zastupanje u osiguranju.

\section{ZAKLJUČAK}

Optimizacijski model za upravljanje provizijskim prihodima omogućuje znanstveno produbljivanje materije industrije osiguranja, unaprjeđenje procesa planiranja i upravljanje procesom ugovaranja osiguranja. Kombiniranjem računovodstvenih informacija sa statističkim regresijskim modelima i matematičkim programiranjem formiraju se nove planske računovodstvene informacije. Te informacije obuhvaćaju planirane vrijednosti bruto premije i provizijske prihode. Planirana vrijednost bruto premije obuhvaćena je po vrstama 
osiguranja i ukupnom portfelju. Prihodi od provizija analiziraju se kroz povećanje godišnje bruto premije koja je limitirana kroz tržišno ograničenje dobiveno primjenom regresijskih trend modela.

Rezultati istraživanja upotpunjuju postojeće metode i tehnike upravljanja u agencijama za zastupanje u osiguranju. Zakonitosti koje su korištene u stvaranju modela omogućuju prepoznavanje onih vrsta osiguranja putem kojih će se efikasno ostvariti planirani prihod. Planirane vrijednosti bruto premije, po vrstama osiguranja, inkorporirane su u finalnu informacijsku bazu koja je postavljena kao konačna ukupna planirana vrijednost prihoda. Rezultat toga je plan prodaje po vrstama osiguranja i vrijednosti bruto godišnje premije uz dodatno pracenje planiranih prihoda i limitiranje gornjih vrijednosti bruto premija.

Usporedbom planiranog povećanja bruto premije i planiranih vrijednosti prihoda iskazanim u relativnim brojevima mogu se analizirati povećanja planiranih prihoda uslijed planiranog povećanja premije, sa ciljem utvrđivanja značajnih faktora koji utječu na visinu ukupnog prihoda portfelja agencija za zastupanje u osiguranju. Ovim postupkom omogućuje se grupiranje osiguranja prema bruto premiji i provizijskim prihodima, te unaprjeđuje proces optimizacije poslovanja. Fleksibilnost modela istaknuta je u njegovoj prilagodbi kroz uvođenje dodatnih ograničenja što omogućuje kreiranje različitih poslovnih scenarija.

\section{LITERATURA}

1. Aczel, A. D., \& Sounderpandian. (2009). Complete Business Statistics, New York: McGraw-Hill Irwin.

2. Andrijanić, I. \& Klasnić, K. (2002). Tehnike osiguranja i reosiguranja, Zagreb: Mikrorad

3. Andrijasevic, S. \& Petranovic, V. (1999). Ekonomika osiguranja, Zagreb: Alfa

4. Brockett, P., \& Xia, X. (1995). Operations Research In Insurance: A Review, Transactions Of Society Of Actuaries, 47, 7-86.

5. David, M. (2015). Auto insurance premium calculation using generalized linear models, Procedia Economics and Finance, 20, 147-156.

6. Drandell, M. (1977). A Resource Association Model for Insurance Management Utilizing Goal Programming, The Journal of Risk and Insurance, Vol. 44 (2), 311-315.

7. Erdemir, K., (2019). Selection of Financial Performance Determinants for Non-Life Insurance Companies Using Panel Data Analysis, The Journal of Accounting and Finance, 82, 251-264

8. Garg, A., Tiwari, A., Dutta. G. \& Basu, S. (2006), A Stochastic Linear Programming Model for Asset Liability Management: The Case of anIndian Insurance Company, Indian Institute Of Management, 10, (08), 1-19

9. Garrido, J., Genest, C. \& Schulz, J. (2019). Generalized linear models for dependent frequency and severity of insurance claims, Insurance: Mathematics and Economics, 70, 205-215.

10. HANFA - Croatian Financial Services Supervisory Agency - Statistics (available at: https://www.hanfa.hr/publikacije/statistika/ access March 20, 2020) 
11. Hilli, P., Koivu. M., Pennanen, T. \& Ranne, A. (2007). A stochastic programming model for asset liability management of a Finnish pension company, Annals of Operations Research, 152 (1), 115-139.

12. HUO - Croatian Insurance Bureau, Retrieved (available at: //www.huo.hr/hrv/statisticka-izvjesca/18/ access March 20, 2020)

13. Krasheninnikova, E. , Javier, G., Maestrea, R. \& Fernández, F. (2019). Reinforcement learning for pricing strategy optimization in the insurance industry, Engineering Applications of Artificial Intelligence, 80, 8-19.

14. Li, S. \& Huang, Z. (1996). Determination of the portfolio selection for a property-liability insurance company, European Journal of Operational Research. 88 (2), 257-268.

15. Narodne novine: Zakon o osiguranju. Zagreb: Narodne novine d.d, 30/15, 112/18, $63 / 20$.

16. Narodne novine: Zakon o računovodstvu. Zagreb: Narodne novine d.d., 78/15, 116/18.

17. Neralić, L. (2012). Uvod u matematičko programiranje, Zagreb, Element

18. Peng, Y., Kou,G., Sabatka, A., Matza, J., Chen, Z., Khazanchi, D. \& Shi, Y. (2007). Application of Classification Methods to Individual Disability Income Insurance Fraud Detection, International Conference on Computational Science - ICCS 2007, 852-858.

19. Rao, H., Dutta, G. \& Basu, S. (2018). New asset liability management model with decision support system for life insurance companies: interface design issues for database and mathematical models, International Journal of Revenue Management, 10(3/4), 259-289.

20. Schleef, H. (2007). Using Linear Programming For Planning Life Insurance Purchases, Decision Sciences, 11(3), 522-534.

21. Sen, S., \& Higle, J.(1999). An Introductory Tutorial on Stochastic Linear Programming Models, Interfaces,Vol. 29, No. 2, 33-61

22. Šošić, I. (2006). Primijenjena statistika, Zagreb: Školska knjiga.

23. Yeo, A., Smith, K., Willis, J. \& Brooks, M. (2002). A mathematical programming approach to optimise insurance premium pricing within a data mining framework, Journal of the Operational Research Society, 53 (11), 1197-1203. 